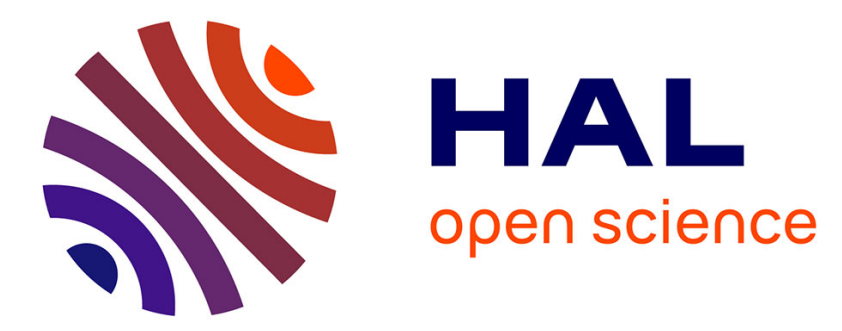

\title{
Unexpected 13C-enrichment of organic components from wheat crop soils: evidence for the in situ origin of soil organic matter
}

Eric Lichtfouse, Sen Dou, Cyril Girardin, Micheline Grably, Jérôme Balesdent, Françoise Béhar, Mireille Vandenbroucke

\section{To cite this version:}

Eric Lichtfouse, Sen Dou, Cyril Girardin, Micheline Grably, Jérôme Balesdent, et al.. Unexpected 13C-enrichment of organic components from wheat crop soils: evidence for the in situ origin of soil organic matter. Organic Geochemistry, 1995, 23 (9), pp.865-868. 10.1016/0146-6380(95)80009-G . hal-00192948

\section{HAL Id: hal-00192948 \\ https://hal.science/hal-00192948}

Submitted on 29 Nov 2007

HAL is a multi-disciplinary open access archive for the deposit and dissemination of scientific research documents, whether they are published or not. The documents may come from teaching and research institutions in France or abroad, or from public or private research centers.
L'archive ouverte pluridisciplinaire HAL, est destinée au dépôt et à la diffusion de documents scientifiques de niveau recherche, publiés ou non, émanant des établissements d'enseignement et de recherche français ou étrangers, des laboratoires publics ou privés. 
Revised version

Organic Geochemistry 23, 865-868, 1995. doi:10.1016/0146-6380(95)80009-G

Correspondence: Dr. Eric Lichtfouse, INRA-CMSE-PME, 17, rue Sully, 21000 Dijon, France

Eric.Lichtfouse@dijon.inra.fr

\title{
Unexpected ${ }^{13} \mathrm{C}$-enrichment of organic components from wheat crop soils: evidence for the in situ origin of soil organic matter
}

\author{
Éric LichtFouse, ${ }^{1 *}$ Sen Dou,${ }^{1,2}$ CYRIL GiRARDin, ${ }^{1}$ Micheline Grably, ${ }^{1}$ \\ JÉRÔME BALESDENT, ${ }^{1}$ FrançOISE BEHAR ${ }^{3}$ and MireILLE VANDENBROUCKE ${ }^{3}$ \\ ${ }^{1}$ Laboratoire de Biogéochimie Isotopique, associé à l'Institut de la Recherche Agronomique, \\ Université Pierre et Marie Curie, Case 120, 75252 Paris CX 05, France, \\ ${ }^{2}$ Department of Soil Science, Jilin Agricultural University, Changchun, China, and \\ ${ }^{3}$ Géochimie Organique, Institut Français du Pétrole, BP 311, 92506 Rueil-Malmaison, France.
}

\begin{abstract}
Various organic constituents extracted from wheat and from soil organic matter have been analysed for their carbon content, their absolute concentration and their stable carbon isotope ratios. Most organic subfractions from plants, or soil, are ${ }^{13} \mathrm{C}$-depleted by up to $9.4 \%$ relative to bulk organic matter, mainly as a result of their higher lipid content. Furthermore, soil organic constituents are unexpectedly ${ }^{13} \mathrm{C}$-enriched by $+1.5 \%$ o to $+4.3 \%$ o relative to homologous plant constituents. Indeed, the selective preservation of plant lignin and lipids, following incorporation into the soil biomass, should have led to the accumulation of ${ }^{13} \mathrm{C}$-depleted compounds. Hence, these results favour the in situ formation of soil organic matter either by recondensation of small molecules or by selective preservation of biopolymers from soil microorganisms.
\end{abstract}

Key words - carbon-13, humic acids, humin, soil lipids, plant alkanes, soil alkanes, pyrolysis of humic acids.

\section{INTRODUCTION}

The decay of plants leads to the preservation of a few percents only of plant carbon into soils, the bulk being rapidly biodegraded then returned to the atmosphere as $\mathrm{CO}_{2}$. Although many bulk chemical properties of soil organic matter are well-known, there is still a lack of understanding of the precise origin, and pathways, of transformation of soil organic substances, notably at the molecular level (Schnitzer and Khan, 1978). The formation of humic substances is believed to occur by two major processes (Hayes et al., 1989): 1) the partial degradation and selective preservation of resistant macromolecules from plants or soil organisms and 2) the polycondensation of small molecules resulting from biomass degradation, e.g. the reaction of amino acids with carbohydrates (Maillard, 1916, 1917). Carbon isotope ratios have been used to define the origin and transformation of organic substances from soils and sediments (Nissenbaum and Kaplan, 1972, Collister et al., 1992, Lichtfouse and Collister, 1992, Macko et al., 1993, Collister et al., 1994a, Lichtfouse et al., 1994ab, Lichtfouse, 1995). In this note we show, using isotopic comparisons of various soil and plant organic substances, that the major part of soil organic matter where wheat has been grown is unlikely to be derived by the selective preservation of the plant's lipids or lignin, and thus must have been formed within the soil.

*Author for correspondence. 


\section{Plant and soil sampling}

\section{EXPERIMENTAL}

Soils, cropped solely with plants following the $\mathrm{C}_{3}$ photosynthetic pathway (O'Leary, 1981), were cored through the 0-35cm ploughed horizon in September 1987 at La Minière, near Versailles, France, after 3 years of wheat cropping (1984-1986). The soil is a dystric eutrochrept, silty loam (Balabane and Balesdent, 1992). The 0-35 $\mathrm{cm}$ ploughed horizon comprises $11.4 \%$ of sand $(50-2000 \mu \mathrm{m}), 73.1 \%$ of silt $(2-50 \mu \mathrm{m})$ and $15.5 \%$ of clay $(0-50 \mu \mathrm{m})$. Two additional soil samples were cored at Boigneville, Essone, France, in 1990 and 1993 after respectively 20 and 23 years of wheat cropping. These soils have very similar characteristics to the soils from the La Minière field (Balesdent et al., 1990). Nine cores, taken at various locations, were well-mixed, dried at $20^{\circ} \mathrm{C}$ then sieved to $2000 \mu \mathrm{m}$. Wheat leaves, stems and roots (Triticum aestivum) were washed with distilled water then freeze-dried at $-20^{\circ} \mathrm{C}$. All samplings and further analyses were repeated three times.

\section{Organic matter fractionation}

Dried soils, leaves, stems and roots were finely ground and extracted ultrasonically $\left(30 \mathrm{~min} ., 30^{\circ} \mathrm{C}, 3 \mathrm{x}\right)$ with $\mathrm{CHCl}_{3}-\mathrm{MeOH}(3 / 1 \mathrm{v} / \mathrm{v})$. Extracts were fractionated into neutral and acid fractions by passage through silica gel impregnated with $\mathrm{KOH}$ followed by $\mathrm{HCO}_{2} \mathrm{H}$ acidification (McCarthy and Duthie, 1962, Collister et $a l .$, 1994a). Neutral fractions were fractionated into hydrocarbon-ester, ketone, alcohol and polar fractions by silica-gel thin layer chromatography, using $\mathrm{CH}_{2} \mathrm{Cl}_{2}$ as developer and 1,2:3,4-dibenzanthracene, friedelin and cholesterol as reference compounds (modified after Lichtfouse et al., 1994c). Neutral fractions were fractionated into alkane-alkene, aromatic and ester fractions by silica-gel thin layer chromatography, with $n$-hexane as developer and using n-octacosane, 1-phenyldodecane, 2-methylphenanthrene and 1,2:3,4-dibenzanthracene as reference compounds. Individual $n$-alkanes from the alkane-alkene fractions were identified by gas chromatography-mass spectrometry, and co-elution with pure standards, and quantified by gas chromatography fitted with a flame ionization detector and using $5 \alpha$-androstane as internal standard.

Ground dry soils were extracted $48 \mathrm{~h}$. at $20^{\circ} \mathrm{C}$ under $\mathrm{N}_{2}$ with $0.1 \mathrm{M} \mathrm{NaOH}$ to give an insoluble fraction (humin and minerals) and a soluble fraction (humic and fulvic acids). Humic acids were separated from the soluble fraction by precipitation at $\mathrm{pH} 1.5$ with $2.4 \mathrm{M} \mathrm{HCl}(3 \mathrm{x})$. Humic acids were further purified by centrifugation at $\mathrm{pH} 7$ to remove most clay particles, dialysed for 10 days against distilled water then freezedried at $-20^{\circ} \mathrm{C}$. Humic acids were pyrolysed at $550^{\circ} \mathrm{C}$ in an open gold tube under continuous argon flow to give pyrolysates and residues.

\section{Isotope analysis}

Isotopic compositions, and carbon contents, were measured on a Carlo Erba NA 1500 elemental $\mathrm{C}$ and $\mathrm{N}$ analyser coupled to a VG Sira 10 mass spectrometer: precision $0.03 \%$, overall deviation $0.1 \%$ (3 replicates). Isotopic analyses of individual $n$-alkanes were carried out under a continuous helium flow using an HP 5890 gas chromatograph coupled to a $\mathrm{CuO}$ furnace $\left(850^{\circ} \mathrm{C}\right)$ and a cryogenic trap $\left(-100^{\circ} \mathrm{C}\right)$ : this system was coupled to a VG Optima mass spectrometer. Ion currents were monitored continuously $(\mathrm{m} / \mathrm{z}=44,45$ and 46 : precision $0.1 \%$, overall deviation $0.3 \%$ o, 3 replicates $)$. Carbon isotope compositions are expressed in per mil. relative to the Pee Dee Belemnite 
Table 1. Chemical composition of wheat and wheat crop soil organic components from the $L a$ Minière field. $\delta^{13} \mathrm{C}$ values of bulk carbon from the Boigneville field are $-25.92 \%$ and $-25.78 \%$ o after wheat cropping during 20 and 23 years, respectively.

\begin{tabular}{lccccc} 
WHEAT & $\begin{array}{c}\text { YIELD } \\
(\mu \mathrm{g} / \mathrm{g} \text { dry weight })\end{array}$ & $\begin{array}{c}\text { CARBON } \\
(\text { weight } \%)\end{array}$ & $\begin{array}{c}\text { CARBON } \\
(\mathrm{mgC} / \mathrm{gCt} \text { Ctal })\end{array}$ & $\begin{array}{c}\delta^{13} \mathrm{C} \\
(\%)\end{array}$ & $\begin{array}{c}\Delta \delta^{\mathrm{a}} \\
(\% \mathrm{o})\end{array}$ \\
\hline Bulk leaf & & 44.99 & 1000 & -29.61 & 0 \\
Bulk stem & & 42.85 & 1000 & -28.47 & 0 \\
Bulk root & 34.36 & 1000 & -27.79 & 0 \\
Leaf organic extract & 26480 & 73.20 & 43.08 & -33.19 & -3.58 \\
Stem organic extract & 7900 & 52.30 & 9.64 & -30.95 & -2.48 \\
Root organic extract & 8568 & 72.90 & 18.18 & -31.64 & -3.85 \\
Leaf $C_{25} n$-alkane & 0.8 & 85.23 & 0.002 & n.d. & \\
Leaf $C_{27} n$-alkane & 4.6 & 85.26 & 0.009 & -35.9 & -6.3 \\
Leaf $C_{29} n$-alkane & 16.5 & 85.29 & 0.031 & -36.5 & -6.9 \\
Leaf $C_{31} n$-alkane & 21.7 & 85.32 & 0.041 & -36.7 & -7.1 \\
Leaf $C_{33} n$-alkane & 7.6 & 85.34 & 0.015 & -36.7 & -7.1
\end{tabular}

\begin{tabular}{|c|c|c|c|c|c|}
\hline SOIL & $\begin{array}{c}\text { YIELD } \\
(\mu \mathrm{g} / \mathrm{g} \text { soil dry weight })\end{array}$ & $\begin{array}{c}\text { CARBON } \\
\text { (weight \%) }\end{array}$ & $\begin{array}{c}\text { CARBON } \\
\text { (mgC/gCtotal) }\end{array}$ & $\begin{array}{c}\delta^{13} \mathrm{C} \\
(\% o)\end{array}$ & $\begin{array}{l}\Delta \delta^{\mathrm{a}} \\
(\% o)\end{array}$ \\
\hline Bulk soil & & $0.95(0.09)^{\mathrm{c}}$ & 1000 & -26.28 & 0 \\
\hline Humin ${ }^{b}$ & & $0.63(0.06)^{\mathrm{c}}$ & 663.6 & -25.59 & +0.69 \\
\hline Humic acids & 1812 & $32.78(3.89)^{\mathrm{c}}$ & 62.52 & -27.45 & -1.17 \\
\hline Humic acids pyrolysate & 89.8 & 62.15 & 5.87 & -26.04 & +0.24 \\
\hline Humic acids pyr. residue & 1028 & 37.14 & 40.19 & -27.64 & -1.36 \\
\hline Organic extract & 161.2 & 61.00 & 10.35 & -28.89 & -2.61 \\
\hline Acid fraction & 38.0 & n.d. & & -29.24 & -2.96 \\
\hline Neutral fraction & 57.0 & n.d. & & -29.40 & -3.12 \\
\hline $\mathrm{C}_{25} n$-alkane & 0.02 & 85.23 & 0.002 & -34.6 & -8.3 \\
\hline $\mathrm{C}_{27} n$-alkane & 0.05 & 85.26 & 0.005 & -34.2 & -7.9 \\
\hline $\mathrm{C}_{29} n$-alkane & 0.16 & 85.29 & 0.014 & -35.7 & -9.4 \\
\hline $\mathrm{C}_{31} n$-alkane & 0.21 & 85.32 & 0.019 & -35.7 & -9.4 \\
\hline $\mathrm{C}_{33} n$-alkane & 0.06 & 85.34 & 0.005 & -35.7 & -9.4 \\
\hline
\end{tabular}

${ }^{a}$ fraction minus bulk. ${ }^{b}$ Analyses were carried out on humin including mineral matrix. ${ }^{c}$ Nitrogen content in parenthesis. n.d.: not determined 
standard: $\quad \delta^{13} \mathrm{C}=\left[\left({ }^{13} \mathrm{C} /{ }^{12} \mathrm{Csample} /{ }^{13} \mathrm{C} /{ }^{12} \mathrm{Cstd}\right)-1\right] \times 10^{3}$, where ${ }^{13} \mathrm{C} /{ }^{12} \mathrm{Cstd}=$ 0.0112372 .

\section{Mass balance}

\section{RESULTS AND DISCUSSION}

Yields, carbon contents and isotope values of various organic fractions from wheat and wheat crop soils from the La Minière field are reported in Table 1. Humin and humic acids amount respectively to 664 and $63 \mathrm{mg}$ carbon per $\mathrm{g}$ of soil organic carbon, and are thus, quantitatively, the most abundant organic components of the soil. Soil and wheat organic extracts, and their subfractions, occur in minor amounts. Nethertheless, they are probably highly involved in soil transformation processes because they represent the "free" part of the organic matter. Moreover, due to their high lipid content, they should be selectively preserved in soils because lipids are more resistant to biodegradation than carbohydrates and amino acids. However, the carbon contents of organic extracts from wheat, averaging $23.6 \mathrm{mg} \mathrm{C}$ per $\mathrm{g}$ of bulk $\mathrm{C}$, are higher than that from soil ( $10.4 \mathrm{mg} \mathrm{C} / \mathrm{g}$ bulk C). Carbon concentrations of individual $n$ alkanes are also higher in wheat leaf than in soil organic matter: $0.041 \mathrm{vs}$. $0.019 \mathrm{mg}$ of carbon per $\mathrm{g}$ of bulk carbon, respectively, for the $\mathrm{C}_{31} n$-alkane. Also, the decrease of soil- vs. plant carbon concentration of organic extracts, and $n$-alkanes, suggests that the selective preservation of lipids is probably not a major pathway in the formation of soil organic matter because a higher content of lipids should have remained in the soils. This view is strenghthened by consideration of carbon isotope ratios, as discussed in the following section.

\section{Wheat and Soil Organic Components}

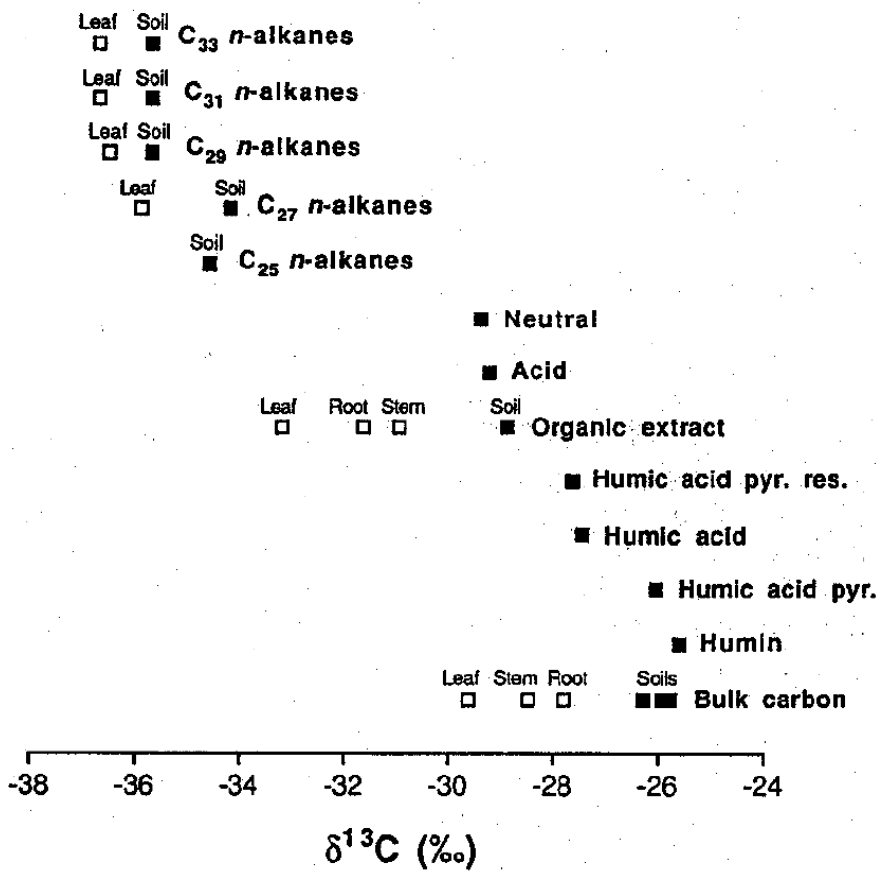

Figure 1. Carbon isotope ratios of various organic components from wheat and wheat crop soils. All data are from the La Minière field, except values of bulk soil carbon from the Boigneville field (-25.92\%o, $25.78 \%$ ). Note the ${ }^{13} \mathrm{C}$-depletion of most soil subfractions versus bulk soil carbon. Note also the ${ }^{13} \mathrm{C}$ enrichment of soil components versus wheat components. 


\section{Carbon isotopic compositions}

Carbon isotope ratios of wheat and soil organic components range respectively from $-36.7 \%$ to $-27.79 \%$ and from $-35.7 \%$ to $-25.59 \%$ (Table 1, Fig. 1). These values are typical of the organic carbon from plants fixing $\mathrm{CO}_{2}$ by the $\mathrm{C}_{3}$ photosynthetic pathway (Nissenbaum and Schallinger, 1974, Deines, 1980, O'Leary, 1981, Collister et al., 1994b, and refs. therein). With the exception of humin and humic acid pyrolysates, all organic subfractions are depleted in ${ }^{13} \mathrm{C}$, reaching a value of $-9.4 \%$ relative to bulk organic carbon. This ${ }^{13} \mathrm{C}$-depletion can be attibuted mainly to the higher lipid content of those organic subfractions relative to the bulk organic matter (Deines, 1980).

Plant lipids and lignin are ${ }^{13} \mathrm{C}$-depleted relative to bulk tissue, whereas amino acids, cellulose and hemicellulose are usually ${ }^{13}$ C-enriched (Deines, 1980, Benner et al., 1987, Schleser, 1992). Since lipids and lignin are more resistant to biodegradation relative to other plant constituents, and since the major part of plant carbon is rapidly recycled to the atmosphere, then the accumulation of plant matter into soil by selective preservation of plant lipids, or lignin, versus polysaccharides should have led to a notable shift of the isotope compositions of soil organic components toward ${ }^{13} \mathrm{C}$ depleted values. For instance, the selective preservation of aliphatic plant components, as a major process, should have given $\delta{ }^{13} \mathrm{C}$ values as low as $-36 \%$ for soil organic matter, as suggested by the $\delta{ }^{13} \mathrm{C}$ values of $n$-alkanes (Fig. 1).

However, we do not observe a depletion but rather a ${ }^{13} \mathrm{C}$-enrichment of $+1.5 \%$ o to $+4.3 \%$ o for soil versus wheat organic components: $+1.5-3.8 \%$ (average $+2.6 \%$ ) for wheat parts vs. bulk soils, $+2.1-4.3 \%$ o (average $+3.0 \%$ ) for wheat part extracts vs. soil extract. Humin also shows a notable ${ }^{13} \mathrm{C}$-enrichment of $+2.2 \%$ to $+4.0 \%$ o (average $+3.0 \%$ ) versus bulk wheat parts. This result is of great significance because humin is the major soil fraction, amounting here to $66 \%$ of soil organic $\mathrm{C}$ and, most important, humin is considered to be the most stable organic component of soils (Schnitzer and Khan, 1978, Hayes et al., 1989, and refs. therein). Moreover, it should be noted that a ${ }^{13} \mathrm{C}$-enrichment ${ }^{*}$ of about $+2 \%$, in deeper horizons versus surface litter, is commonly observed with increasing depth in forest soil profiles (Volkoff and Cerri, 1987, Melillo et al., 1989, Martin et al., 1990, Balesdent et al., 1993). Hence, all these lines of evidence demonstrate that the selective preservation of plant lipids and lignin is not a major pathway of organic matter accumulation into soils. Two other pathways can thus be considered.

Firstly, soil organic matter may be formed by condensation of small molecules from plant degradation products or from soil biomass. The rapid biodegradation of ${ }^{13}$ C-enriched plant polysaccharides (Benner et al., 1987) followed by condensation of carbohydrate monomers with amino acids (Maillard, 1916), which should be ${ }^{13} \mathrm{C}$-enriched, is in good agreement with this hypothesis.

Soil organic matter may alternatively be stored by selective preservation of resistant biopolymers from soil microorganisms consuming ${ }^{13} \mathrm{C}$-enriched plant polysaccharides. Indeed, it has been shown recently that various microorganisms, such

\footnotetext{
${ }^{*}$ Note that the ${ }^{13} \mathrm{C}$-depletion sometimes observed in $\mathrm{C}_{4}$ grassland soils can be attributed to organic matter inherited from paleo C3 vegetation (e.g. Volkoff and Cerri, 1987, Cerling et al., 1989, Mariotti and Peterschmitt, 1994)
} 
as microalgae, cyanobacteria and bacteria, are able to biosynthesize cell wall aliphatic biopolymers which are extremely resistant to acid and alkaline hydrolysis (Chalansonnet et al., 1988, Le Berre et al., 1991, Derenne et al., 1992, de Leeuw and Largeau, 1993). Moreover, the occurrence of these resistant biopolymers in soil is strongly supported by the detection of notable amounts of aliphatic structures within humic acids and humin by NMR studies (Hatcher et al., 1981, 1985, Buddrus and Lambert, 1995).

Whatever pathway is followed during soil organic matter formation, we have shown, on both isotopic and quantitative grounds, that the major part of crop soil humic substances must be formed in situ, either by recondensation of relatively small molecules or by selective preservation of soil biopolymers. Though the formation of soil humic substances by selective preservation of plant lignin and lipids is not excluded, this process is likely to give rise to minor amounts only of crop soil organic carbon.

Acknowledgements-The Institut National de la Recherche Agronomique is gratefully acknowledged for a post-doctoral fellowship for Dr. Sen Dou. We thank Clemence Bosc, Université Pierre et Marie Curie, Dr. May Balabane, I.N.R.A. Versailles and Dr. Claude Largeau, École Nationale Supérieure de Chimie de Paris for helpful discussions. For a critical and helpful review, we are grateful to Prof. John Hayes, Indiana University.

\section{REFERENCES}

Balabane M. and Balesdent J. (1992) Input of fertilizer-derived labelled $\mathrm{N}$ to soil organic matter during a growing season of maize in the field. Soil Biol. Biochem. 24, 89-96.

Balesdent J., Girardin C. and Mariotti A. (1993) Site-related $\delta^{13} \mathrm{C}$ of tree leaves and soil organic matter in a temperate forest. Ecology 74, 1713-1721.

Balesdent J., Mariotti A. and Boisgontier D. (1990) Effect of tillage on soil organic carbon mineralization estimated from ${ }^{13} \mathrm{C}$ abundance in maize fields. J. Soil Sci. 41, 587-596.

Benner R., Fogel M. L., Sprague E. K. and Hodson R. E. (1987) Depletion of ${ }^{13}$ C in lignin and its implications for stable carbon isotope studies. Nature 329, 708-710.

Buddrus J. and Lambert J. (1995) Isolated paraffinic methyl groups in humic substances. Org. Geochem. 23, 269-271.

Cerling T. E., Quade J., Wang Y. and Bowman J. R. (1989) Carbon isotopes in soils and palaeosols as ecology and palaeoecology indicators. Nature 341, 138-139.

Chalansonnet S., Largeau C., Casadevall E., Berkaloff C., Peniguel G. and Couderc R. (1988) Cyanobacterial resistant biopolymers. Geochemical implications of the properties of Schizothrix sp. resistant material. Org. Geochem. 13, 1003-1010.

Collister J. W., Lichtfouse É., Hieshima G. and Hayes J. M. (1994a) Partial resolution of sources of $n$-alkanes of the Parachute Creek Member, Green River Formation (Piceance Creek Basin, Colorado). Org. Geochem. 21, 645-659.

Collister J. W., Rieley G., Stern B., Eglinton G. and Fry B. (1994b) Compoundspecific $\delta^{13} \mathrm{C}$ analyses of leaf lipids from plants with differing carbon dioxide metabolisms. Org. Geochem. 21, 619-627.

Collister J. W., Summons R. E., Lichtfouse É. and Hayes J. M. (1992) An isotopic biogeochemical study of the Green River oil shale. Org. Geochem. 19, 265-276. 
Deines P. (1980) The isotopic composition of reduced organic carbon. In Handbook of Environmental Isotope Geochemistry (Edited by Fritz P. and Fontes J. Ch.), pp. 329406. Elsevier, Amsterdam.

Derenne S., Largeau C., Berkaloff C., Rousseau B., Wilhem C. and Hatcher P. (1992) Non-hydrolysable macromolecular constituents from outer walls of Chlorella fusca and Nanochlorum eucaryotum. Phytochem. 31, 1923-1929.

Hatcher P. G., Breger I. A., Maciel G. E. and Szeverenyi N. M. (1985) Geochemistry of humin. In Humic Substances in Soil, Sediment, and Water (Edited by Aiken G. R. et al.), pp. 275-302. Wiley, New York.

Hatcher P. G., Maciel G. E. and Dennis L. W. (1981) Aliphatic structure of humic acids; a clue to their origin. Org. Geochem. 3, 43-48.

Hayes M. H. B., MacCarthy P., Malcolm R. L. and Swift R. S. (1989) Structures of Humic Substances: the Emergence of "forms". In Humic Substances II, In Search of Structure (Edited by Hayes M. H. B., MacCarthy P., Malcolm R. L. and Swift R. S.), pp. 689-733. Wiley, Chichester.

Le Berre F., Derenne S., Largeau C., Connan J. and Berkaloff C. (1991) Occurrence of non-hydrolysable, macromolecular, wall constituents in bacteria. Geochemical implications. In Organic Geochemistry. Advances and Applications in Energy and

the Natural Environment (Edited by Manning D. A. C.), pp. 428-431. University Press, Manchester.

Leeuw J. W. de and Largeau C. (1993) A review of macromolecular organic compounds that comprise living organisms and their role in kerogen, coal, and petroleum formation. In Organic Geochemistry, Principles and Applications (Edited by Engel M. H. and Macko S. A.), pp. 23-72. Plenum, New York.

Lichtfouse É. (1995) ${ }^{13} \mathrm{C}$ labelling of soil $n$-hentriacontane $\left(\mathrm{C}_{31}\right)$ by maize cultivation. Tetrahedron Lett. 36, 529-530.

Lichtfouse É., Albrecht P., Behar F. and Hayes J. M. (1994c) A molecular and isotopic study of the organic matter from the Paris Basin, France. Geochim. Cosmochim.

Acta 58, 209-221.

Lichtfouse É. and Collister J. W. (1992) Tracing biogenic links of natural organic substances at the molecular level with stable carbon isotopes: $n$-alkanes and $n$ alkanoic acids from sediments. Tetrahedron Lett. 33, 8093-8094.

Lichtfouse É., Derenne S., Mariotti A. and Largeau C. (1994a) Possible algal origin of long chain odd $n$-alkanes in immature sediments as revealed by distributions and carbon isotope ratios. Org. Geochem. 22, 1023-1027.

Lichtfouse É., Elbisser B., Balesdent J., Mariotti M. and Bardoux G. (1994b) Isotope and molecular evidence for direct input of maize leaf wax $n$-alkanes into crop soils. Org. Geochem. 22, 349-351.

Macko S. A., Engel M. H. and Parker P. L. (1993) Early diagenesis of organic matter in sediments. Assessment of mechanisms and preservation by the use of isotopic molecular approaches. In Organic Geochemistry, Principles and Applications

(Edited by Engel M. H. and Macko S. A.), pp. 211-224. Plenum, New York.

Maillard L. C. (1916) Synthèse des matières humiques par action des acides aminés sur les sucres réducteurs. Ann. Chimie (Paris) 5, 258-317.

Maillard L. C. (1917) Identité des matières humiques de synthèse avec les matières humiques naturelles. Ann. Chimie (Paris) 7, 113-152.

Mariotti A. and Peterschmitt E. (1994) Forest savanna ecotone dynamics in India as revealed by carbon isotope ratios of soil organic matter. Oecologia 97, 475-480.

Martin A., Mariotti A., Balesdent J., Lavelle P. and Vuattoux R. (1990) Estimate of organic matter turnover rate in a savanna soil by ${ }^{13} \mathrm{C}$ natural abundance. 
measurements. Soil Biol. Biochem. 22, 517-523.

McCarthy R. D. and Duthie A. H. (1962) A rapid quantitative method for the separation of free fatty acids from other lipids. J. Lipid Res. 3, 117-119.

Melillo J. M., Aber J. D., Linkins A. E., Ricca A., Fry B. and Nadelhoffer K. J. (1989) Carbon and nitrogen dynamics along the decay continuum: plant litter to soil organic matter. Plant and Soil 115, 189-198.

Nissenbaum A. and Kaplan I. R. (1972) Chemical and isotopic evidence for the in situ origin of marine humic substances. Limnol. Oceanogr. 17, 570-582.

Nissenbaum A. and Schallinger K. M. (1974) The distribution of the stable carbon isotope $\left({ }^{13} \mathrm{C} /{ }^{12} \mathrm{C}\right)$ in fractions of soil organic matter. Geoderma 11, 137-145.

O'Leary M. H. (1981) Carbon isotope fractionation in plants. Phytochem. 20, 553-567.

Schleser G. H. (1992) $\delta^{13} \mathrm{C}$ pattern in a forest tree as an indicator of carbon transfer in trees. Ecology 73, 1922-1925.

Schnitzer M. and Khan S. U. (Eds.) (1978) Soil Organic Matter. Elsevier, Amsterdam.

Volkoff B. and Cerri C. C. (1987) Carbon isotopic fractionation in subtropical Brazilian grassland soils. Comparison with tropical forest soils. Plant and Soil 102, 27-31. 